\title{
Optimising the Performance of Cement-Based Batteries
}

\author{
Aimee Byrne, ${ }^{1}$ Shane Barry, ${ }^{1}$ Niall Holmes, ${ }^{1}$ and Brian Norton ${ }^{2}$ \\ ${ }^{1}$ School of Civil \& Structural Engineering, Dublin Institute of Technology, Bolton St., Dublin 1, Ireland \\ ${ }^{2}$ Dublin Energy Lab, Dublin Institute of Technology, Grangegorman, Dublin 7, Ireland \\ Correspondence should be addressed to Aimee Byrne; aimee.byrne@dit.ie
}

Received 10 November 2016; Revised 8 June 2017; Accepted 14 June 2017; Published 20 August 2017

Academic Editor: Kedsarin Pimraksa

Copyright (C) 2017 Aimee Byrne et al. This is an open access article distributed under the Creative Commons Attribution License, which permits unrestricted use, distribution, and reproduction in any medium, provided the original work is properly cited.

\begin{abstract}
The development of a battery using different cement-based electrolytes to provide a low but potentially sustainable source of electricity is described. The current, voltage, and lifespan of batteries produced using different electrolyte additives, copper plate cathodes, and (usually) aluminium plate anodes were compared to identify the optimum design, components, and proportions to increase power output and longevity. Parameters examined include water/cement ratio, anode to cathode surface area ratio, electrode material, electrode spacing, and the effect of sand, aggregate, salts, carbon black, silica fume, and sodium silicate on the electrolyte. The results indicate that the greatest and longest lasting power can be achieved using high proportions of water, carbon black, plasticiser, salts, and silica fume in the electrolyte and using a magnesium anode and copper cathode. This cell produced an open-circuit voltage of $1.55 \mathrm{~V}$, a resistor-loaded peak current over $4 \mathrm{~mA}$, maintaining over $1 \mathrm{~mA}$ for 4 days, and a quasi steady current of $0.59 \mathrm{~mA}$ with a lifespan of over 21 days.
\end{abstract}

\section{Introduction}

For autonomous applications both wind and solar energy systems require batteries or other energy storage mechanisms to merit continuous loads due to the intermittency of their supply. Novel battery design can thus help ease society's dependence on oil, coal, and gas. Research into new forms of battery focuses on creating higher power storage and greater recharge capacity and extending the life of traditional batteries by adapting their components and materials.

Electricity is the flow of electrons through a conductive material initiated by an imbalance of electric charge [1]. Voltage is the amount of potential energy available or work to be done, per unit charge to move electrons through a conductor. In a battery, electrons move from one electrode to another via ionic reactions between the electrode molecules and the electrolyte molecules [1]. These reactions are enabled when there is an external path for electric current (via an electric circuit) and cease when it is broken. During discharge, electrons are transferred from the anode to the cathode via the external wire. Figure 1 displays the basic battery concept with a zinc anode, copper cathode, and sodium chloride $(\mathrm{NaCl})$ solution as the electrolyte. In water,
$\mathrm{NaCl}$ salt splits into sodium $\left(\mathrm{Na}^{+}\right)$and chloride $\left(\mathrm{Cl}^{-}\right)$ions. Zinc atoms dissolve in the electrolyte as ions missing two electrons $\left(\mathrm{Zn}^{2+}\right)$ and combine with two negative chloride ions in the electrolyte to form $\mathrm{ZnCl}_{2}$. Two negatively charged electrons from the dissolved zinc atom are left in the zinc metal $\left(2 \mathrm{e}^{-}\right)$. The water molecules $\left(\mathrm{H}_{2} \mathrm{O}\right)$ in the electrolyte reduce to form molecular hydrogen $\left(\mathrm{H}_{2}\right)$ on the surface of the copper and bubbles out of the solution. The electrons lost in the reaction are replenished by moving two electrons from the zinc through the external wire as shown in Figure 1.

The electrolyte is an ionic conductor [2]. Liquid electrolytes are favoured in batteries as there is a high mobility of ions and continuity of interface between electrode and electrolyte. The main issue with liquid-electrolyte batteries is the use of toxic materials and their tendency to leak during use or after disposal. Solid electrolytes are not prone to leakage but their ionic conductivity tends to be less than their liquid counterparts and are more costly. Some examples of solid electrolytes are polymers doped with ions [3-5] or ceramics with ions arranged to allow substantial movement of same [6-8]. Cement is an ionic conductor due to its pore solution which can be stored in, and travel through, its pores and microcracks as shown in Figure 2. This facilitates 


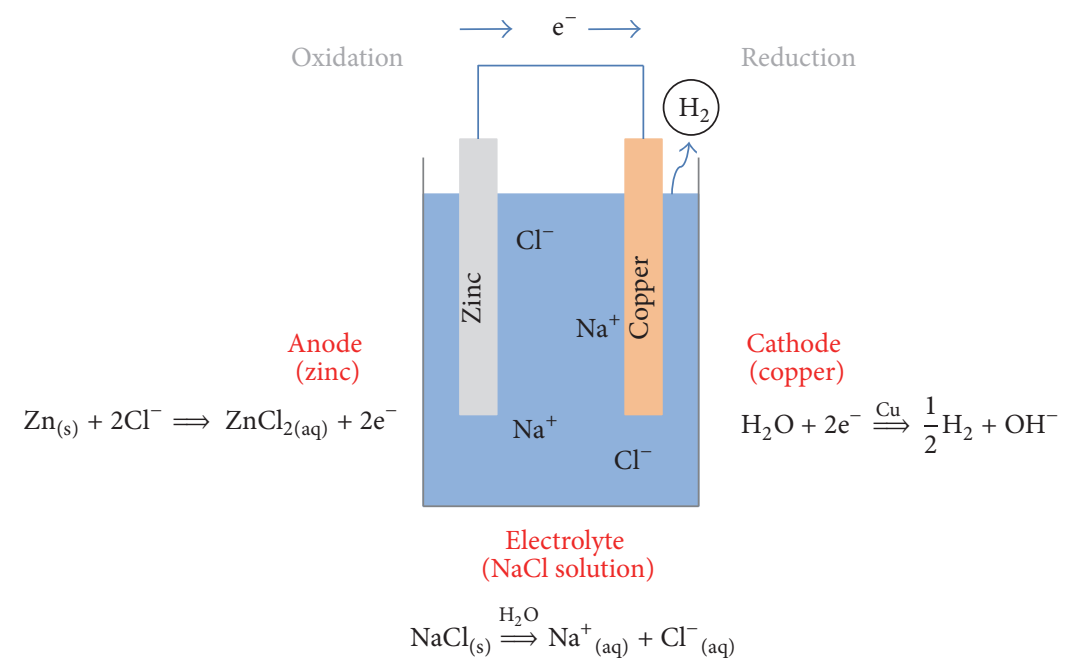

FIGURE 1: Example of basic battery chemical behaviour.

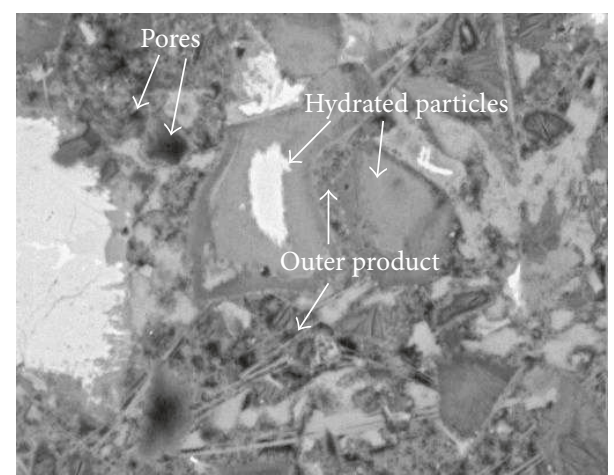

FIGURE 2: Backscattered SEM image of a mature cement paste showing the main microstructural features [9].

its potential as a good electrolyte for novel cement battery designs.

Meng and Chung [2] provided the initial proof of concept that cement-based batteries could indeed be designed to provide a voltage and current output. In their design, cement and water are the common constituents of all layers as shown in Figure 3 with the cathode also containing manganese dioxide particles and the anode layer zinc particles. Carbon black and a water reducing agent were added to both electrode layers. The proposed advantage of this design over the noncement-based electrode probes (Figure 1) is that the active phase is present in all layers (pore solution in the cement paste) and not just at the electrode/electrolyte interface. Manganese dioxide $\left(\mathrm{MnO}_{2}\right)$ is one of the most common cathodic battery materials as it is inexpensive and readily available. Zinc has a wide variety of applications as a negative electrode material in batteries, for example, in alkaline zinc-manganese dioxide, silver-zinc, nickel-zinc, and zinc-air batteries [10]. The carbon was added to increase the conductivity of interface between zinc and cement and to increase its overall electronic conductivity. The output from this battery design was very low with open-circuit voltages of

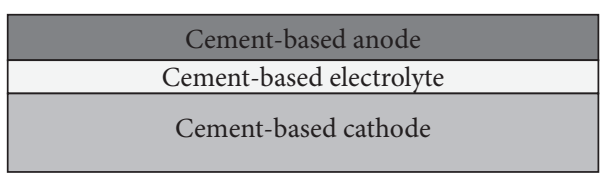

Figure 3: Proof of concept layered battery using cement as the continuous constituent throughout the layers [2].

$0.72 \mathrm{~V}$, with peak currents of $120 \mu \mathrm{A}$ and only operated when completely saturated.

Examples of the successful development of cement batteries tend to follow the Meng and Chung [2] design of electrode cement layers with active additives separated by a basic cement electrolyte. Rampradheep et al. [11] used a similar design adding a self-curing agent to produce a maximum voltage of $0.6 \mathrm{~V}$ and an undisclosed current value. Qiao et al. [12] produced batteries based on the Meng and Chung design [2] and adding carbon fibres and nanotubes in the electrolyte layers which achieved maximum voltages and current densities of approximately $0.7 \mathrm{~V}$ and $35.21 \mu \mathrm{A} / \mathrm{cm}^{2}$. Holmes et al. [13] compared batteries similar to Meng and Chung [2] which were cured in either a deionised water solution or a $0.5 \mathrm{M}$ Epsom salt solution and found that the latter caused a decrease in output with faster drying time and a shorter lifespan. Maintaining a high water content is essential to the life of the layered cement battery.

Examples of electrode-probe type batteries similar to the design of Figure 1 but using cement in the electrolyte tend to focus on corrosion energy harvesting. Burstein and Speckert [14] developed a battery with a steel cathode and an aluminium anode set into a concrete electrolyte that could provide a small current density. Ouellette and Todd [10] developed a seawater battery energy harvester with magnesium and carbon probe electrodes where cement was included in the electrolyte to passively limit the amount of consumable oxygen in deeper water. Holmes et al. [13] showed that limiting cement to the electrolyte greatly 


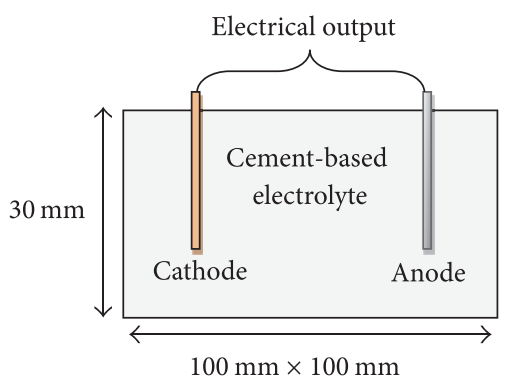

Figure 4: Basic schematic of the battery with cement-based electrolyte.

enhanced both the lifespan and output from cement batteries when compared to the layered design of Figure 3.

This paper presents a parametric experimental study to develop a cement-based battery to provide a reliable and sustainable source of electrical energy. Cement-based battery advancement has not been fully academically investigated up to now although there are many examples of small scale experimentation available on video sharing websites and online energy forums. Because the area is so lightly researched there have not been many advances in making these batteries more efficient, powerful, long lasting, and rechargeable. Here, different cement mix designs are compared with regard to their power output and longevity in order to identify which additives enhance battery output and/or increase its lifespan.

The intended use of the cement batteries presented here is for Impressed Current Cathodic Protection (ICCP) of steel reinforcement in concrete structures. ICCP is a method of protecting reinforcing steel in concrete from corrosion by connecting it to an inert, less noble metal than the steel and running a low level of current through it using an external power source [17]. The recommended design current density is $20 \mathrm{~mA} / \mathrm{m}^{2}$ of the circumferential area of the bars [18] or lower values for fully submerged concrete exposed on both sides of $1 \mathrm{~mA} / \mathrm{m}^{2}$ [19]. Cathodic prevention, which is the provision of protective current before any corrosion has taken place, requires a lower current density of $2-5 \mathrm{~mA} / \mathrm{m}^{2}$ [20]. Therefore the battery testing and development regime presented in this paper focused on enhancing resistor-loaded current and lifespan.

\section{Concept}

2.1. Basic Design. Following on from the findings of Holmes et al. [13] a battery with solid metal electrodes and cement only present in electrolyte was considered most efficient for the application. The standard form of battery chosen is shown in Figure 4 and used to compare different electrolyte and electrode designs while limiting other characteristics such as size and shape. The base battery consisted of a cement and water paste to form the electrolyte, a copper plate cathode, and an aluminium plate anode. The size of the cell is irrelevant to its voltage; however, it does affect its internal resistance, which in turn affects the maximum current that a cell can provide [1]. Therefore, all batteries except for the electrode ratio examinations were designed to the same size. Spacing between electrodes was maintained at $100 \mathrm{~mm}$, except for the electrode spacing tests.

2.2. Cement Electrolyte. As discussed in Section 1 a good electrolyte is an ionic conductor which facilitates the movement of charge across it. There are a number of examples of ionic solution migration through hardened concrete. Chloride ions are considered to be the most dominant cause for corrosion of embedded reinforced steel in concrete [21,22] and can ingress through absorption, diffusion, wicking, and capillary action through an interconnected pore network. The process of corrosion of embedded steel in concrete is another example of ionic flow through set concrete. During corrosion, iron atoms are removed from the steel surface by electrochemical reaction and then dissolve into the surrounding electrolyte solution, which in concrete can only occur where pores meet the reinforcing steel surface at the anode. As it is a redox reaction, electrons must transfer from the anode to a cathodic site which gains in electrons. The transfer of electrons occurs along the metal and creates a current between areas of differing potential. The ions from the reactions such as the ferrous ion $\left(\mathrm{Fe}^{2+}\right)$ pass into the solution trapped in the concrete pores and react with hydroxyl ions $\left(\mathrm{OH}^{-}\right)$to form ferric hydroxide which further reacts to form rust as shown in Figure 5.

Ionic flow through concrete pores can also be encouraged or forced using ionic extraction techniques. These techniques are used to protect concrete steel reinforcement from corrosion by drawing the ions away. Cathodic protection is essentially the reversal of the corrosion process, acting as an electrochemical cell by introducing an external anode and applying a small current onto the reinforcement, forcing it to act as the cathode (as opposed to the dissolving anode) in an electrochemical cell [23]. Chloride extraction is similar to cathodic protection but it involves a much higher current density and is a once-off application. The ionic conductivity of cement can be increased by increasing the proportion of solution in the paste, thereby increasing the pore volume and the amount of solution in the pores. It can also be increased by enhancing the ionic conductivity of the solution itself by adding constituents whose chemicals dissociate readily to form free ions, for example, salts.

2.3. Electrodes. The amount of voltage (electromotive force) generated by any battery is specific to the particular chemical reaction for that cell type. Chemical interactions where electrons are transferred directly between molecules and atoms are called oxidation-reduction or (redox) reactions. In a battery the anode and the cathode undergo oxidation and reduction, respectively. The galvanic series of metals displayed in Table 1 is in the presence of seawater. Aluminium and copper were chosen due to being highly anodic and cathodic, respectively, resulting in an expected electromotive potential of $2 \mathrm{~V}(0.34 \mathrm{~V}+1.66 \mathrm{~V})$ for the base battery design.

Theoretically the proportion of cathode to anode should be determined using their oxidation and reduction reactions (see (1) and (2)) and their molar mass resulting in a design 


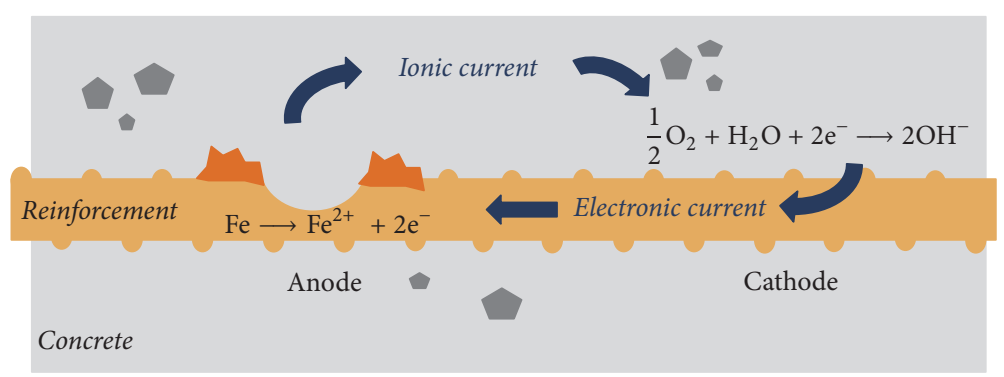

FIgURE 5: Process of embedded steel reinforcement providing an example of ionic flow in concrete [13].

TABle 1: Partial standard electromotive force series as measured against a hydrogen reference electrode [15].

\begin{tabular}{|c|c|c|}
\hline Material & & Standard electrode potential (V) \\
\hline Magnesium & $\uparrow$ & -2.363 \\
\hline Aluminium & $\breve{g}$ & -1.662 \\
\hline Zinc & ఏ્子 & -0.763 \\
\hline Iron & & -0.440 \\
\hline Nickel & $\underline{u}$ & -0.250 \\
\hline Copper & تृ & +0.345 \\
\hline Platinum & 密 & +1.200 \\
\hline Gold & $\downarrow$ & +1.498 \\
\hline
\end{tabular}

of 2.5 parts copper $(\mathrm{Cu})$ to 1 part aluminium $(\mathrm{Al})$. However a proportion of $1: 1$ was taken in the base designs before this theory was tested.

$$
\begin{aligned}
\mathrm{Al}_{(\mathrm{s})} & \longrightarrow \mathrm{Al}_{(\mathrm{aq})}^{3+}+3 \mathrm{e}^{-} \\
\mathrm{Cu}_{(\mathrm{aq})}^{2+}+2 \mathrm{e}^{-} & \longrightarrow \mathrm{Cu}_{(\mathrm{s})}
\end{aligned}
$$

A common issue with metals, particularly highly anodic materials, is the formation of oxide layers (a thin layer of reaction product). Aluminium reacts with oxygen very rapidly and forms aluminium oxide $\left(\mathrm{Al}_{2} \mathrm{O}_{3}\right)$ in the atmosphere. Copper also forms an oxide layer when exposed to air, but these reactions are slower and mainly consist of $\mathrm{Cu}_{2} \mathrm{O}$ and $\mathrm{CuO}$ [23]. These oxide layers can impede the output of the battery as it reduces the interface between the electrodes and electrolyte. Such layers can be removed by scraping using sand paper or washing with acetic acid and rinsing with a volatile liquid such as ethanol [2] prior to addition to the mix.

\section{Methodology}

3.1. Preparation. Materials of the highest purity were chosen so that their specific impact could be distinguished from the potential impact of their impurities. Materials were also chosen to be nontoxic if leaked so that these batteries could offer an advantage over many conventional liquid-electrolyte types. Details on the material used in the batteries are summarised in Table 2.

A water/cement ratio of 0.4 was used as the basic electrolyte design. The electrolyte materials were weighed and passed through a $200 \mu \mathrm{m}$ sieve to remove any nonconforming lumps or bulk to achieve the desired powder format. The dry constituents were mixed well with deionised water and placed into $100 \times 100 \times 30 \mathrm{~mm}$ plastic moulds $(300 \times 120 \times 50 \mathrm{~mm}$ for electrode ratio testing) to create the electrolyte block.

The $60 \times 30 \times 0.5 \mathrm{~mm}$ electrode plates were sanded and washed in a borax solution to remove any impurities and inserted into the wet electrolyte block protruding $5 \mathrm{~mm}$ from the surface to facilitate connection to the resistor circuit. Batteries were then placed on a vibration table for 30 seconds to remove any remaining air and allowed to cure for 24 hours under a polythene sheet after which testing began.

3.2. Data Acquisition. Open-circuit voltage and continuous voltage $(V)$ readings during current discharge $(I)$ through a $10 \Omega$ resistor $(R)$ were recorded over the life of the batteries. Current discharge through the resistor was calculated from the voltage readings using Ohm's law $(I=V / R)$.

A $10 \Omega$ resistor was connected between the anode and cathode of the battery to act as a resistor load as per Figure 6 . A LabVIEW National Instruments differential data acquisition (DAQ) unit NI 9205 was used to record voltage either side of the resistor as shown in the same schematic. Pilot testing using a multimeter refined the frequency of readings and provided likely ranges of measured current and voltages. These values allowed for a suitable LabVIEW programme to be finalised (Figure 6). The setup was calibrated against a DC power unit and volt meter. Logged files from the LabVIEW programme were written into CSV (comma separated values) format and imported directly into MS Excel after testing was complete.

3.3. Battery Design and Reasoning. Seven different components were examined for their effect on resistor-loadedcurrent, open-circuit voltage, and lifespan. These were the water/cement ratio (WC 1-4), the anode to cathode ratio (Al 4:1 Cu-Al 4:4 Cu), basic additives (Add 1-6), 0.5 M salt solutions to replace water (Soln 1-Soln 3), salt added as solid crystals (Crys 1-2), sodium silicate as full and partial water replacement and as a coating to the plates (SS 1-3), electrode spacing (Sp 1-5), carbon black proportion (CB 1-4), and the effect of using different electrode materials (El 1-4). The proportions of the mix designs, materials, and electrode spacing are presented in Table 3 . Add 1 and Add 5, shown in bold, were often used as base mixes from which to compare other batteries. The average dry weight of each cell was $335 \mathrm{~g}$. 
TABLE 2: Details of cement battery materials.

\begin{tabular}{|c|c|c|}
\hline Element & Material & Details \\
\hline \multirow{6}{*}{ Electrolyte } & Carbon black & Porous carbon agglomerates; average size $30 \mathrm{~nm}$ \\
\hline & Cement & CEM I complying with BS EN 197-1, 2000 [16] \\
\hline & Water reducer & Sika VistoCrete 30HE \\
\hline & Salts ( $\mathrm{NaCl}$, Alum \& Epsom salt) & Over $99 \%$ purity for all \\
\hline & Sand and lightweight aggregate & Sand $0.4 \mathrm{~mm}$, expanded clay aggregate $15 \mathrm{~mm}$ \\
\hline & Sodium silicate & Density of $1.38 \mathrm{~g} / \mathrm{cm}^{3}(40 \mathrm{Be})$ and a $\mathrm{pH}$ of 11.3 \\
\hline \multirow{3}{*}{ Anode } & Zinc plates & $>99 \%$ purity \\
\hline & Aluminium plates & $>99 \%$ purity \\
\hline & Magnesium alloy plates & $96 \%$ purity ( $3 \%$ aluminium \& $1 \%$ zinc) \\
\hline \multirow{2}{*}{ Cathode } & Copper plate & $99.5 \%$ purity, $0.4 \mathrm{~mm}$ thick \\
\hline & Carbon & Graphite rod \\
\hline
\end{tabular}

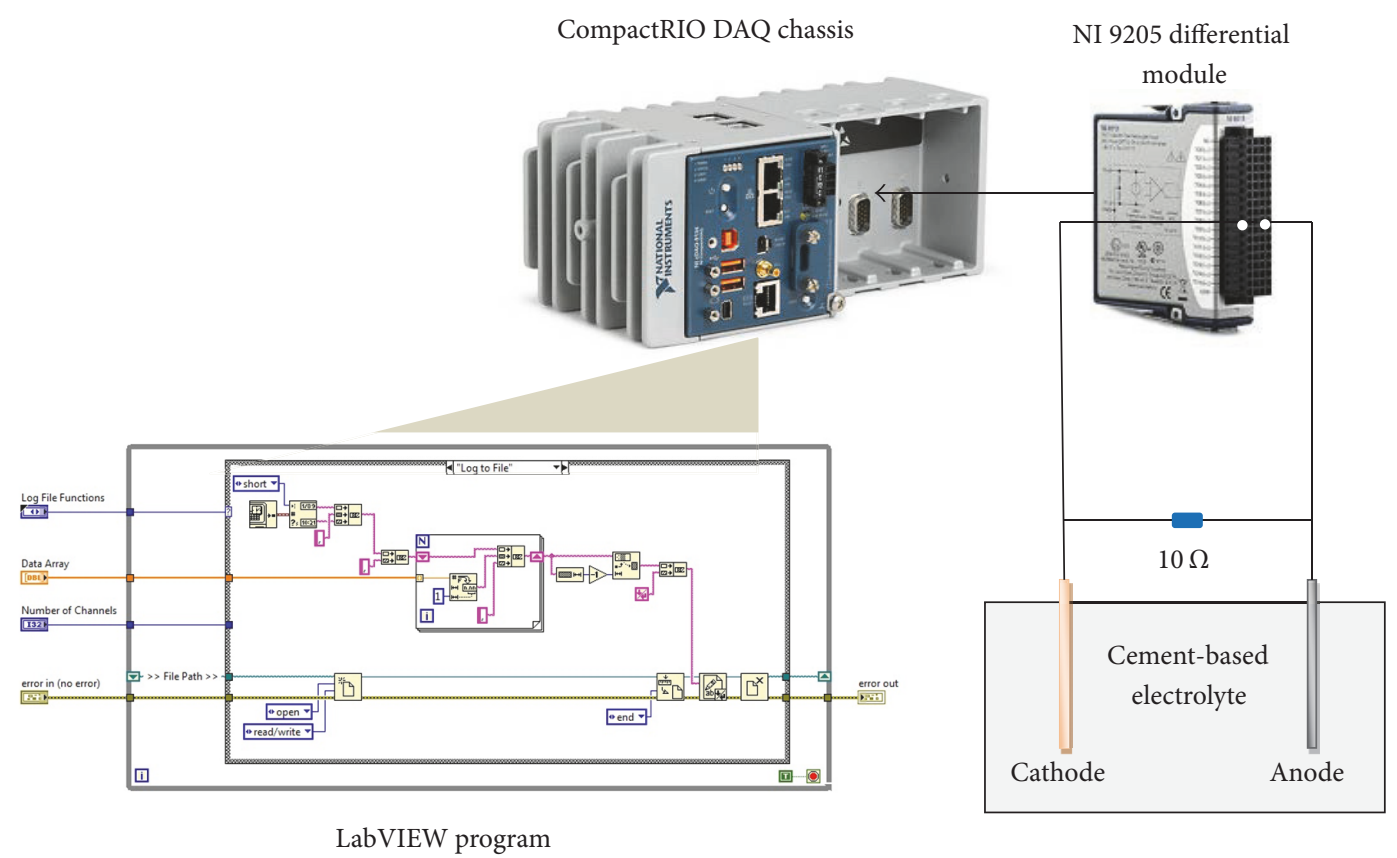

FIgURE 6: LabVIEW voltage recording across the battery's $10 \Omega$ resistor load.

3.3.1. Water/Cement Ratio. The pore water solution in set cement mixes provides the network for ions to travel allowing the transfer of charge and the production of current. Therefore, the relationship between water/cement ratio (and therefore the volume of water in the cement pores) and the performance of the battery was compared by adjusting the $\mathrm{w} / \mathrm{c}$ ratio between 0.3 and 0.6 and recording the output.

3.3.2. Anode/Cathode Ratio. Theoretically when designing a battery the ratio of anode to cathode can be calculated as discussed in Section 2.3 using their molar mass. For aluminium and copper this should be approximately Al 2.5:1 $\mathrm{Cu}$. Therefore the ratio of anode to cathode was examined here by altering the ratios in favour of the anode or the cathode.

As discussed in Section 2.3, the greater the surface area of contact between the electrodes and electrolyte is, the greater the current should be and there should be no effect on voltage. Therefore, an increase in both anode and cathode material was also examined.

3.3.3. Additives. The rigidity of the battery was enhanced by adding sand (Add 2) or lightweight expanded clay aggregate (Add 3 ) to the base mix design (Add 1). Plasticiser is generally added to allow for a reduction in the amount of water needed while maintaining workability. However, as a reduction in water would lead to a reduction in pores and pore solution, the volume of water added to the mix was not reduced for Add 4. Add 5 included carbon black as an admixture as it is known to increase electronic conductivity and formed the base carbon black mix for comparison with batteries that included carbon black along with other developments. Silica fume has been shown to improve the mechanical properties and durability of cement [20]. Silica fume was introduced as 
TABle 3: Cement battery designs.

\begin{tabular}{|c|c|c|c|c|c|c|c|c|}
\hline Ref. & $\begin{array}{l}\text { CEM I } \\
(\mathrm{g})\end{array}$ & $\begin{array}{l}\text { Water } \\
(\mathrm{g})\end{array}$ & Anode & Cathode & $\mathrm{Pl}(\mathrm{g})$ & $\mathrm{CB}(\mathrm{g})$ & $\begin{array}{c}\text { Additive }(\mathrm{g}) \text { or space between } \\
\text { electrodes }(\mathrm{mm})\end{array}$ & Photo \\
\hline WC 1 & 300 & 90 & $\mathrm{Al}$ & $\mathrm{Cu}$ & & & & \\
\hline WC 2 & 300 & 120 & $\mathrm{Al}$ & $\mathrm{Cu}$ & & & & \\
\hline WC 3 & 300 & 150 & $\mathrm{Al}$ & $\mathrm{Cu}$ & & & & \\
\hline WC 4 & 300 & 180 & $\mathrm{Al}$ & $\mathrm{Cu}$ & & & & \\
\hline $\mathrm{Al} 4: 1 \mathrm{Cu}$ & 900 & 360 & $\mathrm{Al}$ & $\mathrm{Cu}$ & 15 & 5 & & \\
\hline $\mathrm{Al} 3: 1 \mathrm{Cu}$ & 900 & 360 & $\mathrm{Al}$ & $\mathrm{Cu}$ & 15 & 5 & & \\
\hline $\mathrm{Al} 2: 1 \mathrm{Cu}$ & 900 & 360 & $\mathrm{Al}$ & $\mathrm{Cu}$ & 15 & 5 & & \\
\hline $\mathrm{Al} 1: 1 \mathrm{Cu}$ & 900 & 360 & $\mathrm{Al}$ & $\mathrm{Cu}$ & 15 & 5 & & \\
\hline $\mathrm{Al} 1: 2 \mathrm{Cu}$ & 900 & 360 & $\mathrm{Al}$ & $\mathrm{Cu}$ & 15 & 5 & & \\
\hline $\mathrm{Al} 1: 3 \mathrm{Cu}$ & 900 & 360 & $\mathrm{Al}$ & $\mathrm{Cu}$ & 15 & 5 & & \\
\hline $\mathrm{Al} 1: 4 \mathrm{Cu}$ & 900 & 360 & $\mathrm{Al}$ & $\mathrm{Cu}$ & 15 & 5 & & \\
\hline $\mathrm{Al} 4: 4 \mathrm{Cu}$ & 900 & 360 & $\mathrm{Al}$ & $\mathrm{Cu}$ & 15 & 5 & & \\
\hline Add 1 & 300 & 120 & $\mathrm{Al}$ & $\mathrm{Cu}$ & & & & \\
\hline Add 2 & 300 & 120 & $\mathrm{Al}$ & $\mathrm{Cu}$ & & & $100 \mathrm{~g}$ sand & \\
\hline Add 3 & 300 & 120 & $\mathrm{Al}$ & $\mathrm{Cu}$ & & & $100 \mathrm{~g}$ agg & \\
\hline Add 4 & 300 & 120 & $\mathrm{Al}$ & $\mathrm{Cu}$ & 5 & & & \\
\hline Add 5 & 300 & 120 & Al & $\mathrm{Cu}$ & 5 & 5 & & \\
\hline Add 6 & 300 & 120 & $\mathrm{Al}$ & $\mathrm{Cu}$ & 5 & 5 & $100 \mathrm{~g}$ silica fume & \\
\hline Soln 1 & 300 & - & $\mathrm{Al}$ & $\mathrm{Cu}$ & 5 & 5 & $120 \mathrm{~g} 0.5 \mathrm{M} \mathrm{NaCl}$ & \\
\hline Soln 2 & 300 & - & $\mathrm{Al}$ & $\mathrm{Cu}$ & 5 & 5 & $120 \mathrm{~g} \mathrm{0.5} \mathrm{M} \mathrm{Epsom}$ & \\
\hline Soln 3 & 300 & - & $\mathrm{Al}$ & $\mathrm{Cu}$ & 5 & 5 & 120 g 0.5 M Alum & \\
\hline Crys 1 & 300 & 120 & $\mathrm{Al}$ & $\mathrm{Cu}$ & 5 & 5 & $100 \mathrm{~g}$ Epsom salt & \\
\hline Crys 2 & 300 & 120 & $\mathrm{Al}$ & $\mathrm{Cu}$ & 5 & 5 & $100 \mathrm{~g}$ Alum salt & \\
\hline SS 1 & 300 & - & $\mathrm{Al}$ & $\mathrm{Cu}$ & 5 & 5 & $120 \mathrm{~g}$ sodium silicate & \\
\hline SS 2 & 300 & 100 & $\mathrm{Al}$ & $\mathrm{Cu}$ & 5 & 5 & $20 \mathrm{~g}$ sodium silicate & \\
\hline SS 3 & 300 & 120 & $\mathrm{Al}$ & $\mathrm{Cu}$ & 5 & 5 & Sodium silicate coating & \\
\hline Sp 1 & 300 & 120 & $\mathrm{Al}$ & $\mathrm{Cu}$ & 5 & 5 & $5 \mathrm{~mm}$ & \\
\hline $\mathrm{Sp} 2$ & 300 & 120 & $\mathrm{Al}$ & $\mathrm{Cu}$ & 5 & 5 & $10 \mathrm{~mm}$ & \\
\hline Sp 3 & 300 & 120 & $\mathrm{Al}$ & $\mathrm{Cu}$ & 5 & 5 & $30 \mathrm{~mm}$ & \\
\hline Sp 4 & 300 & 120 & $\mathrm{Al}$ & $\mathrm{Cu}$ & 5 & 5 & $60 \mathrm{~mm}$ & \\
\hline Sp 5 & 300 & 120 & $\mathrm{Al}$ & $\mathrm{Cu}$ & 5 & 5 & $80 \mathrm{~mm}$ & \\
\hline CB 1 & 300 & 120 & $\mathrm{Al}$ & $\mathrm{Cu}$ & 5 & 3 & & \\
\hline CB 2 & 300 & 120 & $\mathrm{Al}$ & $\mathrm{Cu}$ & 5 & 4.5 & $\vec{x}$ & 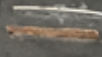 \\
\hline CB 3 & 300 & 120 & $\mathrm{Al}$ & $\mathrm{Cu}$ & 5 & 6 & $1-x^{2}$ & \\
\hline $\mathrm{CB} 4$ & 300 & 120 & $\mathrm{Al}$ & $\mathrm{Cu}$ & 5 & 7.5 & & \\
\hline El 1 & 300 & 120 & $\mathrm{Mg}$ & $\mathrm{Cu}$ & 5 & 5 & & \\
\hline El 2 & 300 & 120 & $\mathrm{Al}$ & $\mathrm{Cu}$ & 5 & 5 & 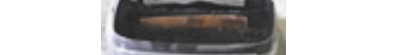 & \\
\hline El 3 & 300 & 120 & $\mathrm{Zn}$ & $\mathrm{Cu}$ & 5 & 5 & $\mathrm{Cu}^{+} \mathrm{Al}$ & $\mathrm{Cat}$ \\
\hline El 4 & 600 & 230 & $\mathrm{Al}$ & $\mathrm{C}$ & 12 & 12 & & \\
\hline
\end{tabular}


an additive to the base mix alongside conductive carbon black and plasticiser as Add 6.

3.3.4. Salts. Pure water is not very conductive; however, when salt is dissolved in it, salt molecules readily split and provide additional ions in the fluid as discussed in Section 1. Add 5, which contained carbon black and plasticiser, was used as the base mix for the salt batteries. 0.5 Molar solutions of sodium chloride $(\mathrm{NaCl})$, Alum salt $\left(\mathrm{AlKO}_{8} \mathrm{~S}_{2} \cdot 12 \mathrm{H} 2 \mathrm{O}\right)$, and Epsom salt $\left(\mathrm{MgSO}_{4} \cdot 7 \mathrm{H}_{2} \mathrm{O}\right)$ were made up using deionised water. These solutions were used as total water replacements when compared to the base mix as Soln 1, Soln 2, and Soln 3. Alum (Crys 1) and Epsom salts (Crys 2) were also added to the base Add 5 mix as solid crystals and the water content was maintained as per the base mix.

3.3.5. Sodium Silicate. Sodium silicate is typically added to concrete to reduce its porosity by forming calcium silicates which fill the pores reducing water permeability [21]. Sodium silicate was added to the base mix design as full replacement (SS 1) and partial replacement (SS 2) of water content. The solution was further used to coat the electrodes (SS 3) in an attempt to reduce the gas which had been observed surfacing in the electrolyte at the aluminium anode plate thereby increasing the smoothness of the electrode/electrolyte interface.

3.3.6. Electrode Proximity. The cement electrolyte layer is kept as thin as possible to reduce resistance in layered batteries [2]. The base paste mix (Add 5) was used to compare electrode spacing of $5,10,30,60$, and $80 \mathrm{~mm}$. This is examined in order to determine whether the volume of electrolyte between the electrodes had any significant influence on performance.

3.3.7. Carbon Black. Carbon black (CB) particles are very small, have high porosity, and can form long branched chains which result in improving the electrical conductivity of the compound such as conductive plastic composites [24]. It was used in previous battery designs $[2,11,13]$ to enhance the connectivity between electrode particles or in cement batteries to create a more intimate interface between the active electrode material and the cement $[2,25]$. However, in the arrangement under investigation here, carbon black cannot be added to the electrodes as they are solid plates and is instead added as an admixture to the cement electrolyte.

The addition of carbon black makes the hardened cement brittle [13]. It was therefore decided to determine the effects of increasing the proportion of carbon black in the design on output while not impinging on the rigidity of the block. Carbon black was added to the base mix design by 3, 4.5, 6 , and $7.5 \mathrm{~g}$ alongside $5 \mathrm{~g}$ of plasticiser $(\mathrm{Pl})$ so that no additional water was required (which would increase the brittleness).

3.3.8. Electrode Material. As discussed in Section 2.3 the electrode material and the respective electromotive force potentials control the voltage of any battery cell. The designs so far (Sections 3.3.1-3.3.8) used copper and aluminium electrodes. The base design (Add 5) was used to compare different electrode materials $\mathrm{Al}: \mathrm{Cu}(\mathrm{El} \mathrm{1)}, \mathrm{Mg}: \mathrm{Cu}$ (El 2), $\mathrm{Zn}: \mathrm{Cu}(\mathrm{El}$ 3), and $\mathrm{Al}: \mathrm{C}(\mathrm{El} 4)$. The plate sizes were maintained the same to allow for direct comparison with the exception of El 4 as carbon could only be sourced in probe form with a greater surface area in which case the aluminium anode volume had to be increased to match it. These materials each possess different electromotive potentials as presented in Table 1 where different combinations should present the different voltages.

\section{Results and Discussion}

4.1. Parameters of Interest. The following sections present the current discharge curves on a logarithmic scale to show the effect of the different parameters discussed in Sections 3.3.1-3.3.8 in terms of current discharge through a $10 \Omega$ resistor and lifespan.

4.2. Water/Cement Ratio. The open-circuit voltage and lifespan were unaffected by the increasing water content. However, a direct correlation exists between the water content and the current under resistor load as shown in Figure 7. A pattern of increased current of 3.5-5\% was observed for every 0.1 increases in water/cement ratio. Any higher water content resulted in the water settling out of the mix during curing.

The pore structure, shape, size, distribution, and connectivity affect the movement of ions in a cement battery electrolyte [21]. Lower w/c ratios have been shown to result in smaller porosity and constrictivity (depends on the ratio of the diameter of the diffusing particle to the pore diameter) as well as a higher tortuosity factor (property of pathway being tortuous) [26]. The work presented here reflects the findings of these simulations as low $\mathrm{w} / \mathrm{c}$ ratios resulted in lower current outputs from the battery cells due to the reduced connectivity and volume of pores.

4.3. Anode/Cathode Ratio. A ratio of anode to cathode as per molar mass calculation which would lead to a balancing of reactions in the electrode materials did not lead to a greater output from the cells. Instead the more general trend of more electrode material resulting in higher current was observed (Figure 8). Open-circuit voltage was not impacted as the electromotive force of the electrode materials remained the same (around 1.2 V), but more current was produced with the higher anode and cathode volumes as more chemical reactions were facilitated.

4.4. Additives. As may be seen in Figure 9, the addition of sand, lightweight aggregate, or plasticiser showed no significant impact on current, voltage, or lifespan. Carbon black was found to slightly increase the voltage (by approximately $0.15 \mathrm{~V}$ ) and improved the flow of electric charge (current) with a better discharge life to over 7 hours. The addition of silica fume on top of carbon black further increased both the current and lifespan but had no further impact on open-circuit voltage. Silica fumes relationship with ionic conductivity in cement is complex. It has been shown to reduce the overall electrical conductivity of cement paste and reduce porosity $[27,28]$; however, at higher proportions it 


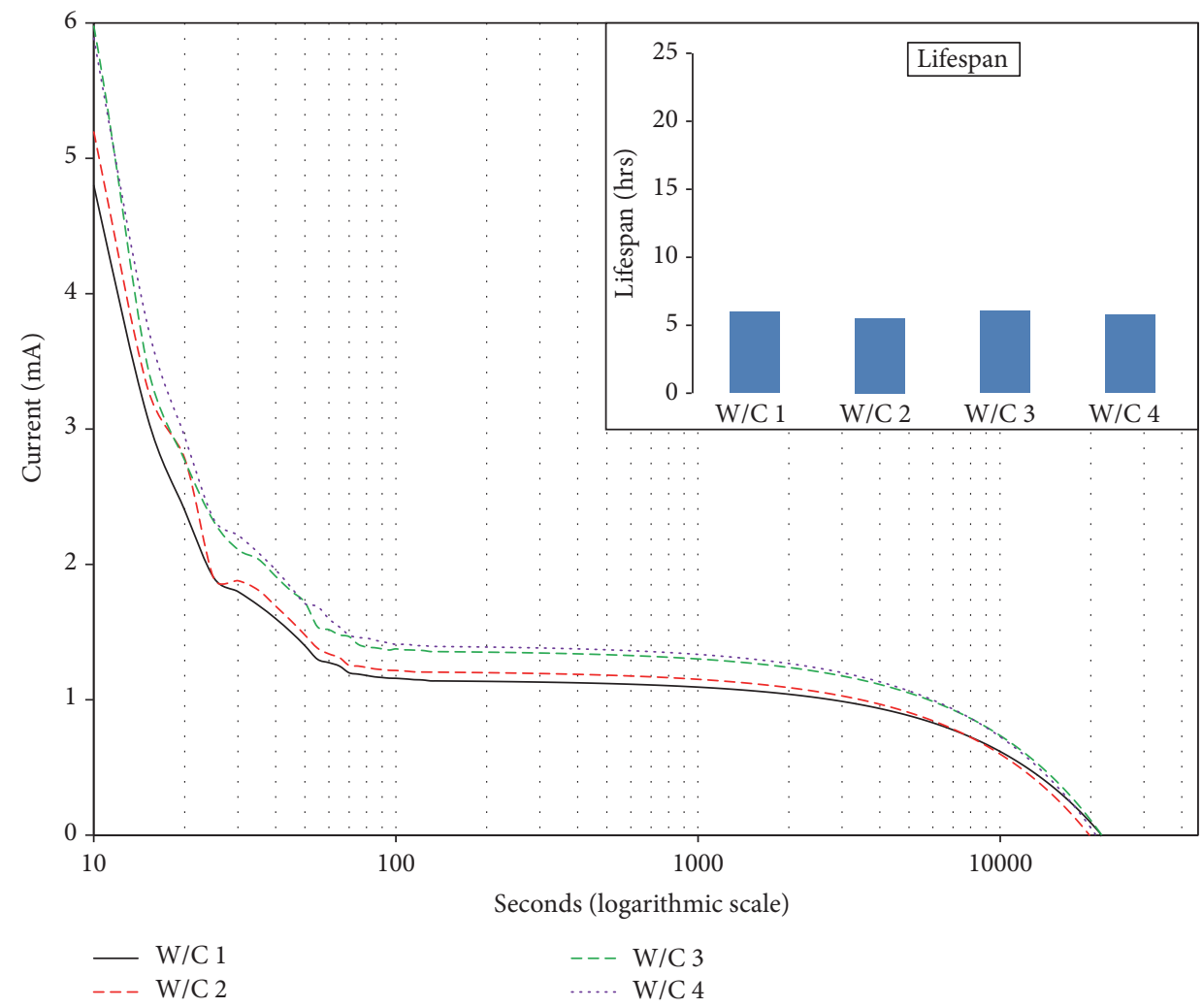

Figure 7: Current discharge curves across a $10 \Omega$ resistor for increasing w/c ratio.

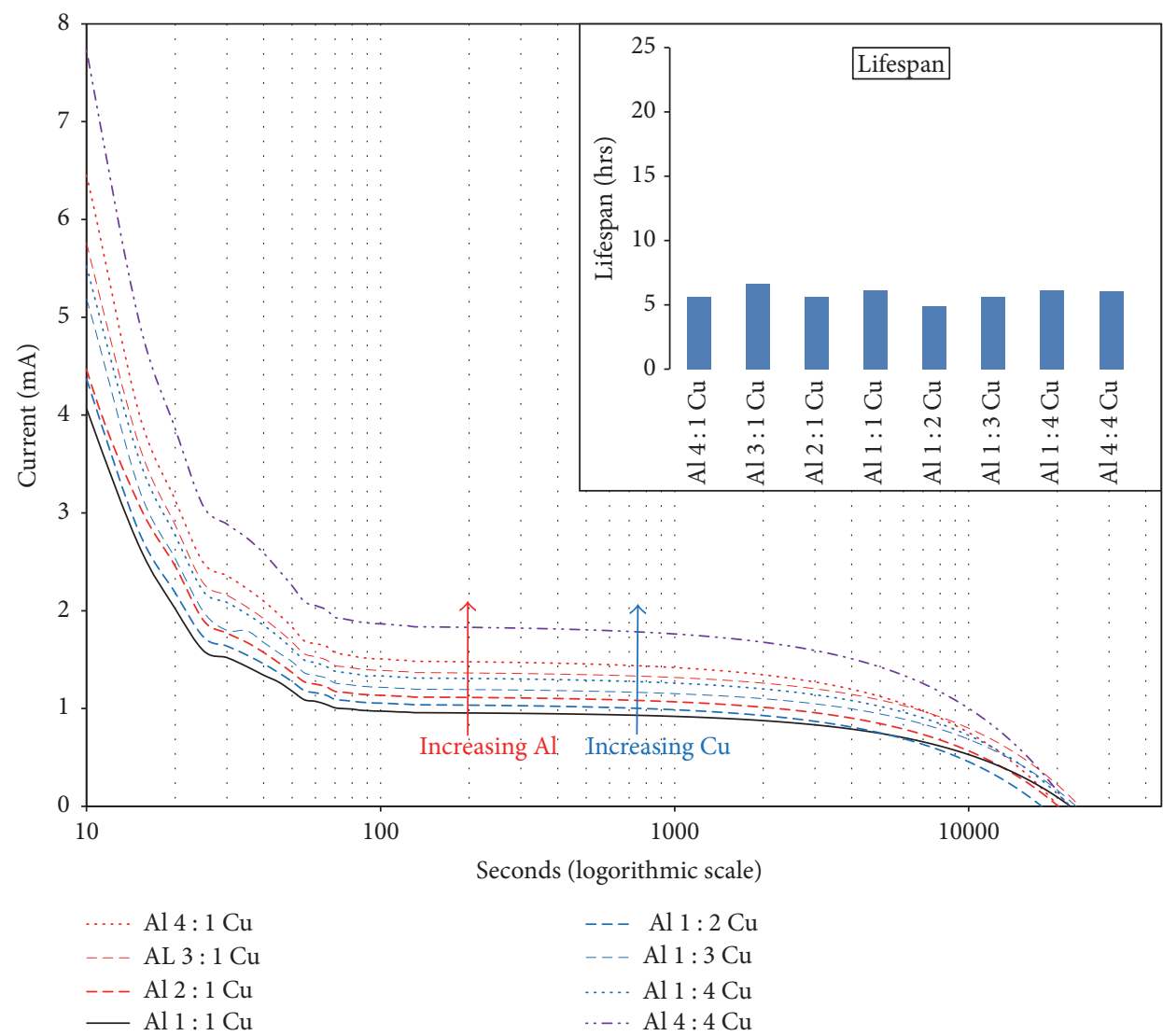

Figure 8: Current discharge curves across a $10 \Omega$ resistor for different anode to cathode ratios. 


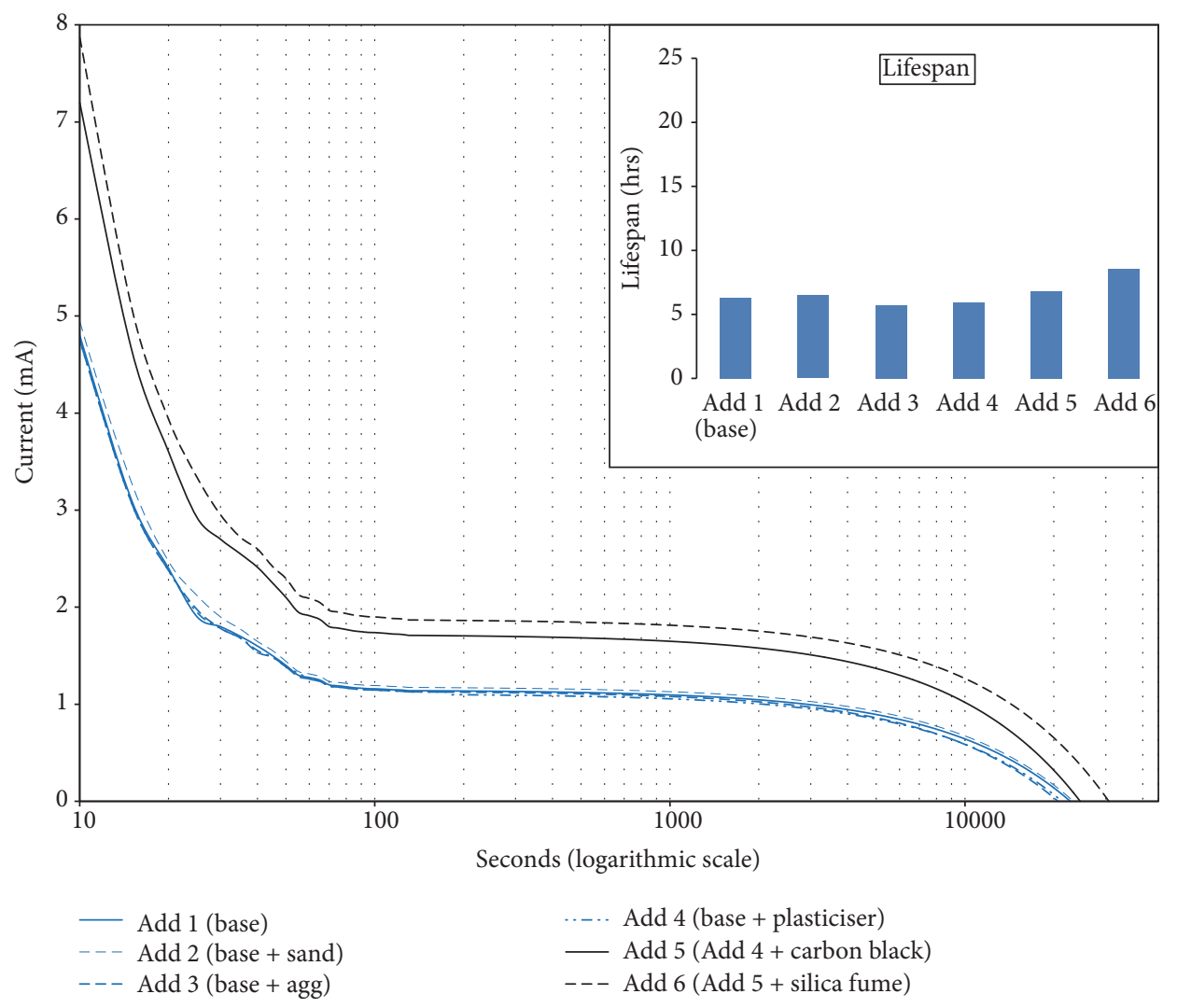

FIGURE 9: Current discharge curves across a $10 \Omega$ resistor for different additives.

can increase the porosity of the paste [28] which is associated with increasing ionic conductivity. However, similar to these findings, silica fume has previously been shown to increase the electrical conductivity of cement pastes containing conductive additives such as carbon fibres by improving their dispersion in the mix $[29,30]$.

4.5. Salts. The addition of salt, whether in solution or raw crystal form, to the electrolyte significantly increased the battery lifespan and improved the flow of electric charge as shown in Figure 10. The base mix contained only deionised water in the solution. In the other three battery designs different 0.5 Molar salt solutions were used. Compared to the base mix, the use of salt solutions led to an increase in current output by approximately $20 \%$ from $1.69 \mathrm{~mA}$ to $2.02 \mathrm{~mA}$. The lifespan of the batteries was greatly increased by approximately $50 \%$ from $6.82 \mathrm{hrs}$ to $9.77-12.17 \mathrm{hrs}$. Although salt solution increased current and longevity, adding it in solid granule form was also beneficial increasing current by $15 \%$ from $1.69 \mathrm{~mA}$ to $1.90 \mathrm{~mA}$ and lifespan by $62.5 \%$ from $6.82 \mathrm{hrs}$ to $12.54-12.57 \mathrm{hrs}$.

4.6. Sodium Silicate. Sodium silicate is typically added to concrete to reduce porosity and water penetration which would inhibit ionic flow. However, it has a high conductive ion concentration in the pore solution and therefore has shown a higher passing of charge than other activation materials in alkali-activated slag mortars [31]. The electrical conductivity of most ordinary silicate glasses is due to the motion of alkali ions, especially sodium [32]. The total replacement of water with sodium silicate (SS 1) reduced both current and lifespan of the battery to almost nothing as seen in Figure 11. Its addition as a partial water replacement (SS 2) showed no significant impact when compared to the base design with currents within $0.02 \mathrm{~mA}$ of each other and lifespan within half an hour.

In Burstein and Speckert's work [14] a swelling of the electrolyte system was observed during setting of the concrete due to hydrogen evolution at the aluminium anode. This was also observed in the batteries presented here as bubbles observed between the anode and the concrete electrolyte. Coating the anode with sodium silicate (SS 3) was an attempt to provide ions for the hydrogen to react with forming harmless water; however, this did not result in any improvement in output.

4.7. Electrode Proximity. Figure 12 shows no discernible correlation in between electrode spacing and current, lifespan, or open-circuit voltage. Current was within $0.05 \mathrm{~mA}$ of the base mix, lifespan within 43 minutes, and open-circuit voltage within $0.08 \mathrm{~V}$.

4.8. Carbon Black. Carbon black has been shown to increase output, particularly current and longevity as found in Section 4.4. As may be observed in Figure 13, there is a clear correlation between carbon black content and both current 


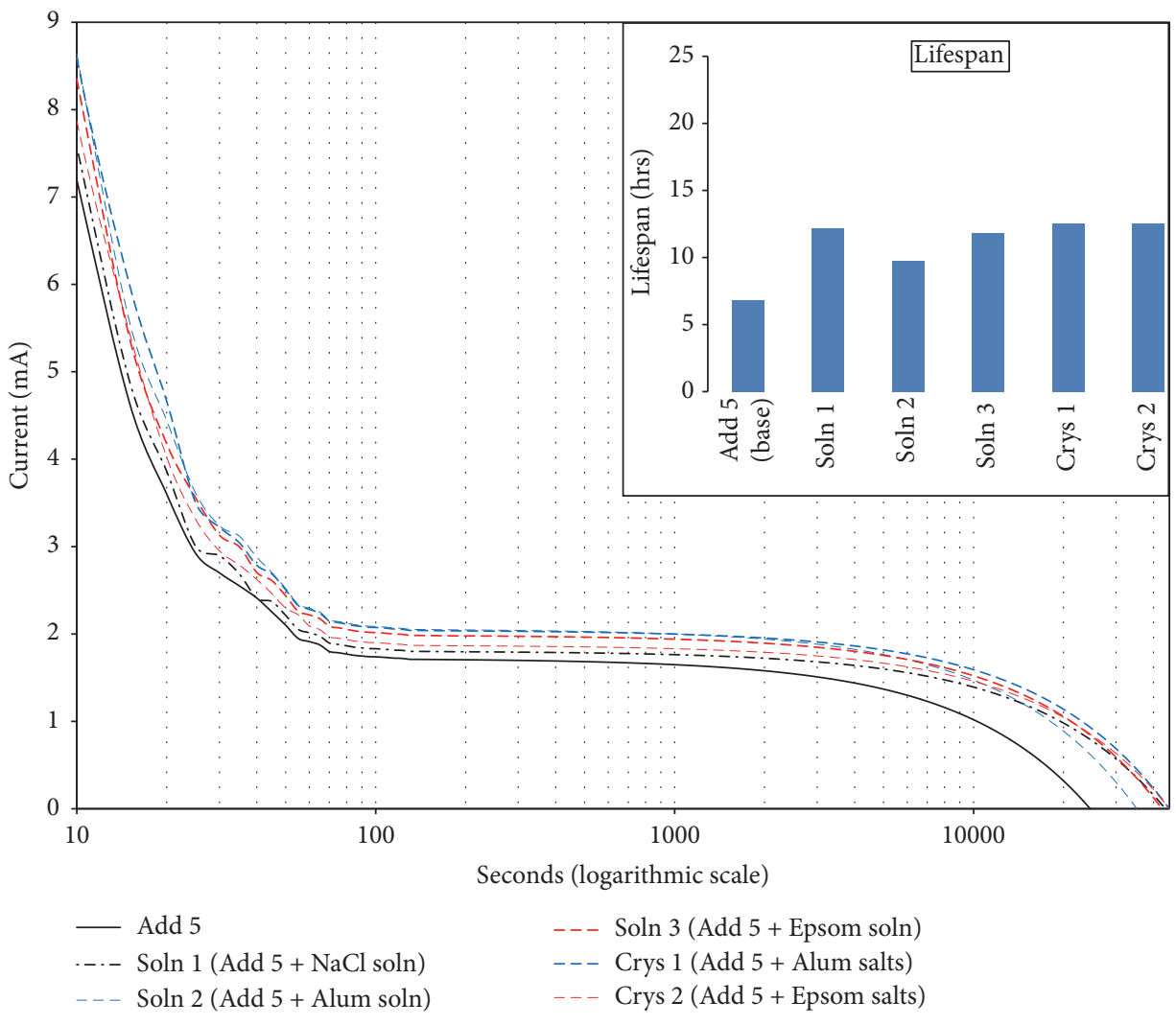

Figure 10: Current discharge curves across a $10 \Omega$ resistor for different salts.

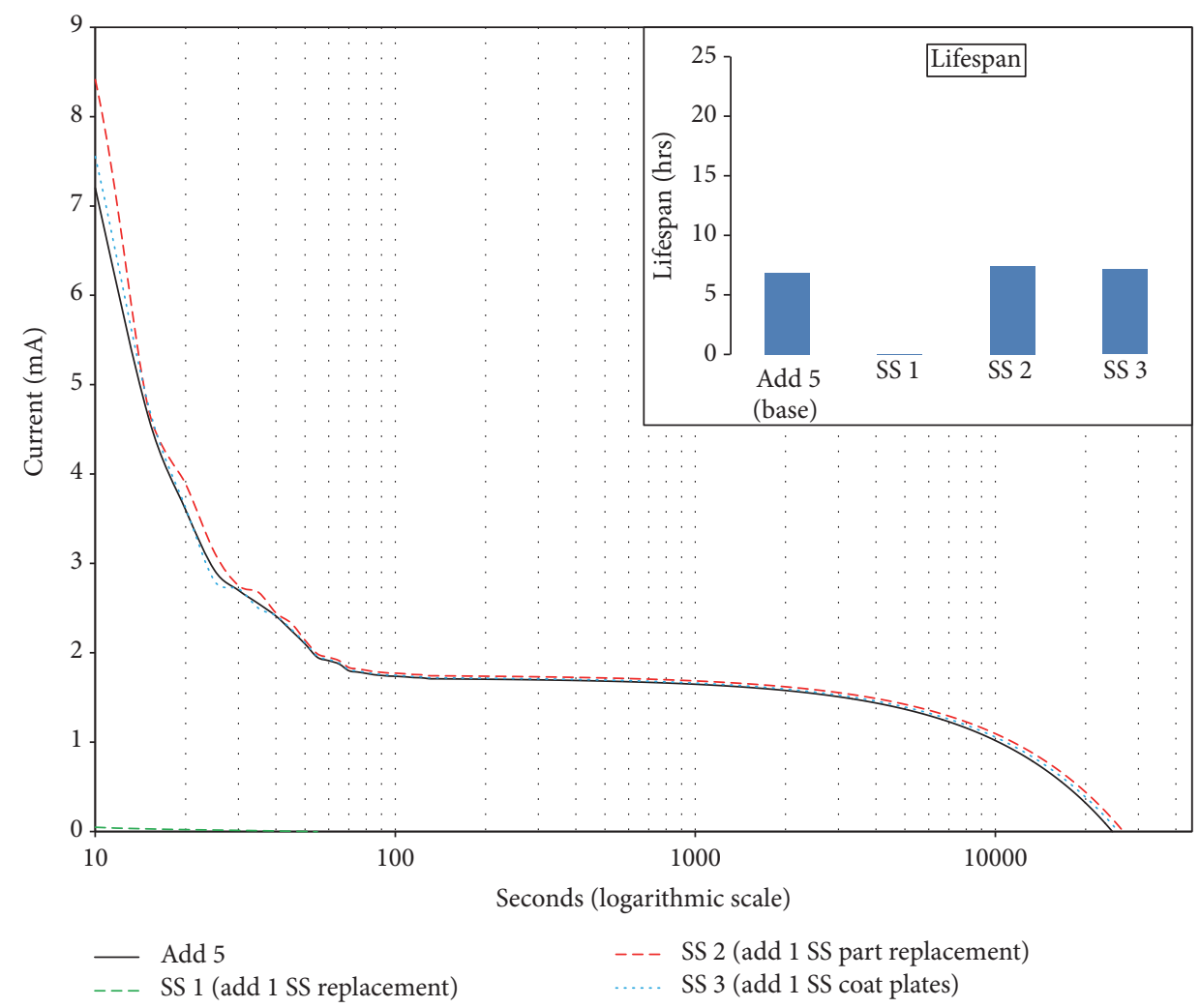

FIGURE 11: Current discharge curves across a $10 \Omega$ resistor for sodium silicate additive. 


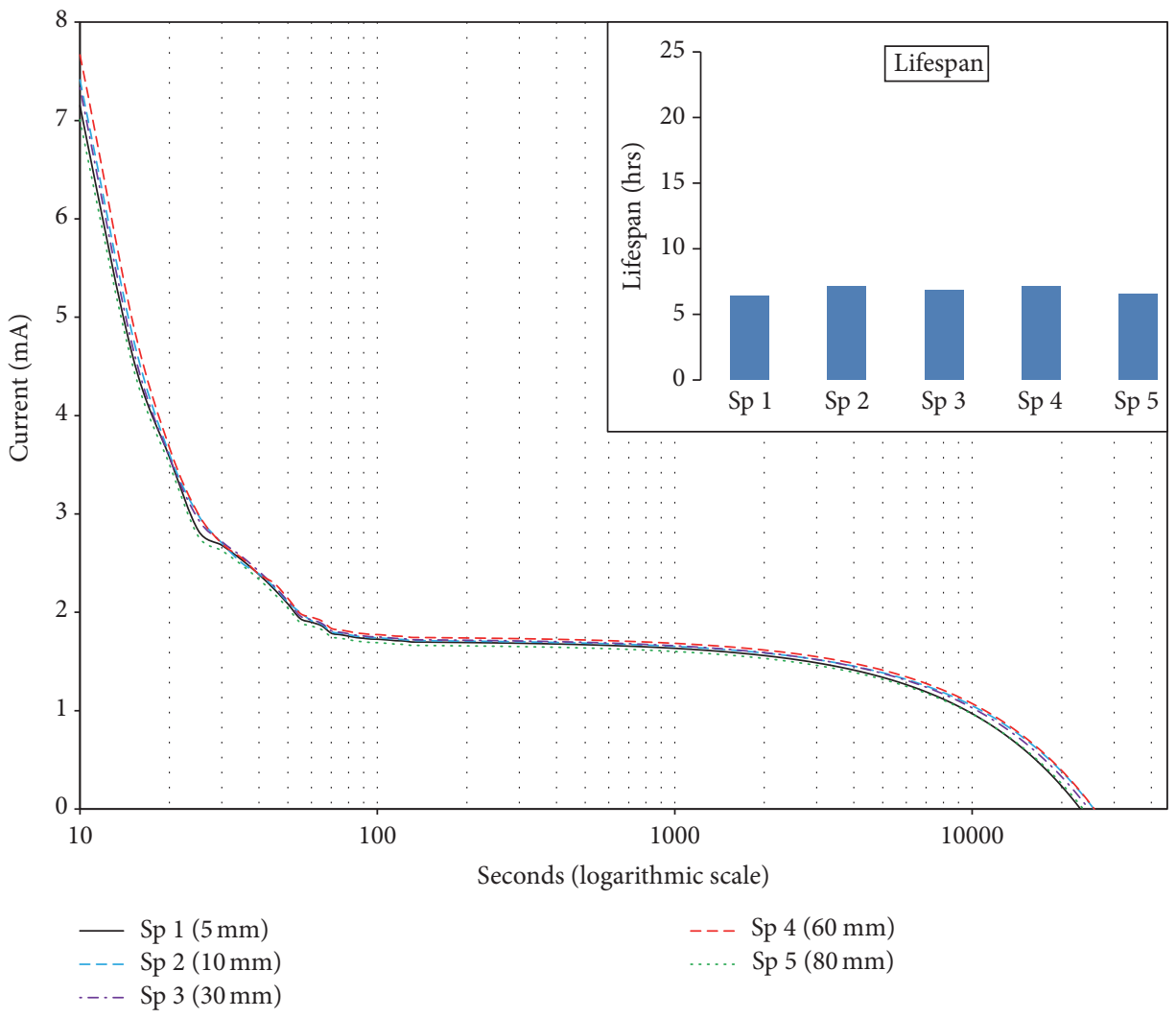

FIGURE 12: Current discharge curves across a $10 \Omega$ resistor for increasing electrode spacing.

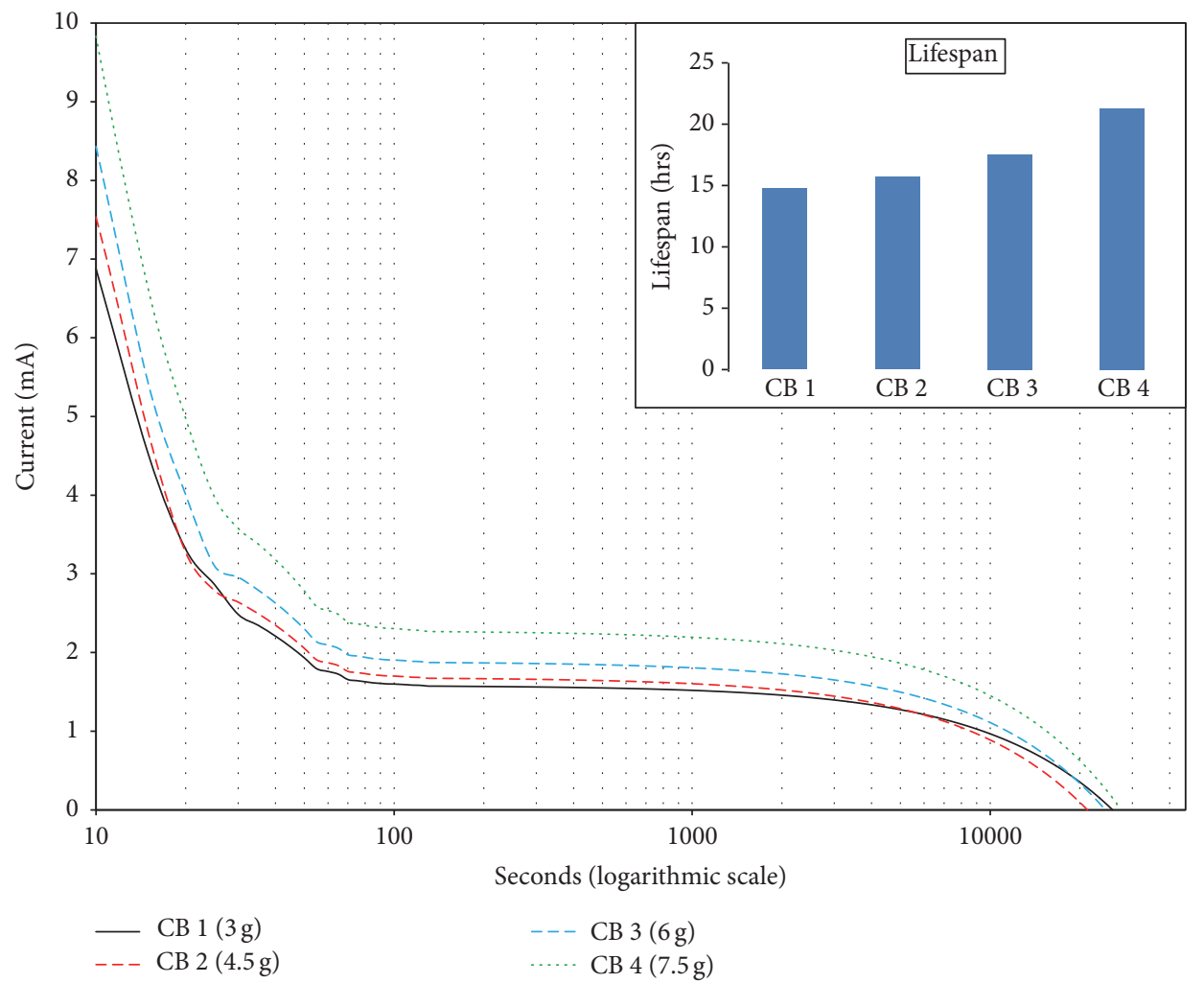

FIGURE 13: Current discharge curves across a $10 \Omega$ resistor with increasing carbon black content. 
TABLE 4: Overview of findings.

\begin{tabular}{lccc}
\hline Variable & Current (under $10 \Omega$ load) & Voltage (initial open-circuit) & Lifespan \\
\hline Increase w/c ratio & $\uparrow$ & $=$ & $=$ \\
Sand & $=$ & $=$ & $=$ \\
Aggregate & $=$ & $\uparrow$ & $\uparrow$ \\
Silica fume & $\uparrow$ & $=$ & \\
Carbon black (+plasticiser) & $\uparrow$ & $=$ & $=$ \\
Increase electrode material & $\uparrow$ & $=$ & \\
Salt solution & $\uparrow$ & $=$ & \\
Salt crystals & $\uparrow$ & $=$ & \\
Sodium silicate & $=$ & $\uparrow$ \\
Closer electrodes & $=$ & $\uparrow$ \\
Magnesium anode & $\uparrow$ & $\uparrow$ \\
\hline
\end{tabular}

output and lifespan. As its proportion by weight increases from $0.7 \%$ to $1.7 \%$, the resting current increases from $1.5 \mathrm{~mA}$ to $2.2 \mathrm{~mA}$ (44\%), open-circuit voltage increases from 1.3 to $1.4 \mathrm{~V}(13 \%)$, and lifespan increased from under 15 hours to over 21 hours (33\%), respectively. Due to the fineness of carbon black particles its addition makes cells considerably more brittle [13] and inclusion of a plasticiser proved to be essential when using carbon black in the cement paste in these proportions.

Carbon black particles have a graphite-type crystalline structure, which improves electrical conductivity and is, therefore, more typically used in electrode materials $[33,34]$. It is therefore likely that the increase in voltage is due to the carbon black particles in contact with the electrode. In the electrolyte, the movement of charge in the cell involves the generation and consumption of both ions and electrons. High reaction activity is achieved when transport rates are high for both ions and electrons. Furthermore, similar increases in ionic conductivity have been found in previous studies using carbon black in polymer mixes where it was speculated that the carbon black may contain a small number of mobile ions that are able to contribute to ionic conductivity upon exposure to moisture [35]. Modified carbon materials including carbon black have also previously been added to enhance the ionically conductive pathways of polymer-ionic liquid electrolytes [36]. For these tests the wealth of electrons in the carbon and the affinity with the ions in the polymer facilitated ion dissociation and transportation through the electrolyte.

4.9. Electrode Material. Replacing the aluminium anode with magnesium greatly increased the current, voltage, and lifespan of the cell as shown in Figure 14. Replacing the copper cathode with carbon also showed a benefit; however, the total size of the El 4 cell was double that of the other cells due to the available carbon cathode size meaning that a direct comparison cannot be made.

Copper was consistently used as the cathode material as it is highly noble. Comparing aluminium, zinc, and magnesium anodes, it can be seen that magnesium produced a substantial improvement in all areas, particularly current and longevity. Magnesium is one of the most active materials (Table 1)

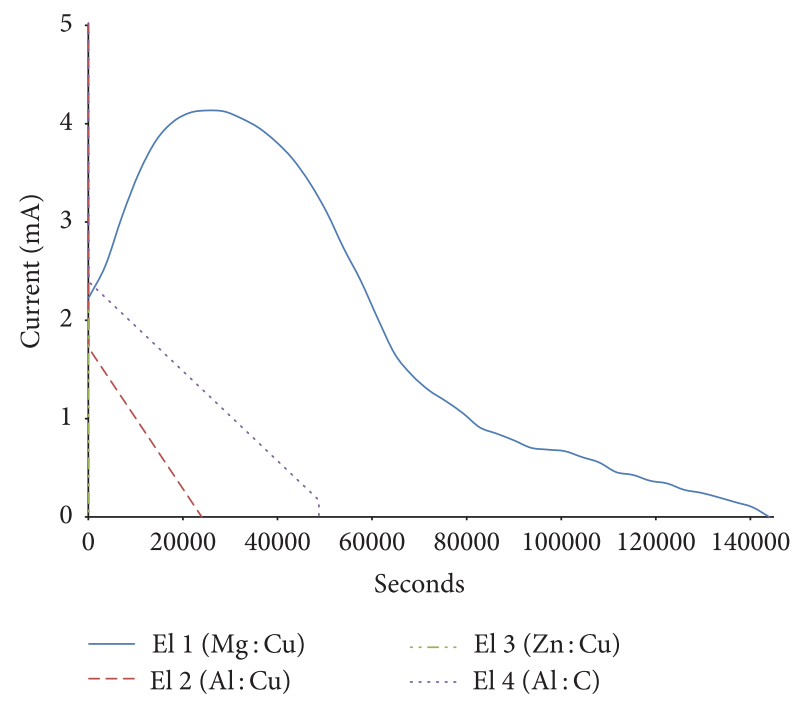

FIGURE 14: Current discharge curves across a $10 \Omega$ resistor for different electrode combinations (note: this is not a logarithmic scale).

followed by zinc and then aluminium [37]. The measured open-circuit voltages for El 1 and El 2 reflect this at $1.553 \mathrm{~V}$ for $\mathrm{Mg}: \mathrm{Cu}$ and $1.311 \mathrm{~V} \mathrm{Al}: \mathrm{Cu}$. However, the value for zinc measured to be $0.059 \mathrm{~V}$. It can therefore be presumed that an error occurred during the zinc test, by short circuiting the battery, or that the zinc plates were sealed or had an oxide layer that was not removed adequately, thus creating a barrier between the anode and the electrolyte. This is an area where further investigation is required.

4.10. Results Summary. Table 4 presents a summary of the impact of each individual change in battery constituent or proportion on loaded current, open-circuit voltage, and lifespan. Cases listed as equal include minor changes (below $0.1 \mathrm{~mA}, 0.2 \mathrm{~V}$, or 1 hour) or where no discernible pattern was identified.

Initial battery testing, with prioritised current and lifespan, indicates that optimal output could be achieved by designing high w/c ratios, using magnesium as the anode 
TABLE 5: Final battery design.

\begin{tabular}{lcccccccc}
\hline $\begin{array}{l}\text { CEM I } \\
(\mathrm{g})\end{array}$ & $\begin{array}{c}\text { Water } \\
(\mathrm{g})\end{array}$ & $\begin{array}{c}\text { Carbon black } \\
(\mathrm{g})\end{array}$ & $\begin{array}{c}\text { Plasticiser } \\
(\mathrm{g})\end{array}$ & $\begin{array}{c}\text { Silica fume } \\
(\mathrm{g})\end{array}$ & $\begin{array}{c}\text { Epsom salt } \\
(\mathrm{g})\end{array}$ & $\begin{array}{c}\text { Alum salt } \\
(\mathrm{g})\end{array}$ & $\begin{array}{c}\text { Magnesium anode } \\
(\mathrm{mm})\end{array}$ & $\begin{array}{c}\text { Copper cathode } \\
(\mathrm{mm})\end{array}$ \\
\hline 300 & 176 & 6 & 5 & 20 & 50 & 50 & $60 \times 30 \times 0.5$ & $60 \times 30 \times 0.5$ \\
\hline
\end{tabular}

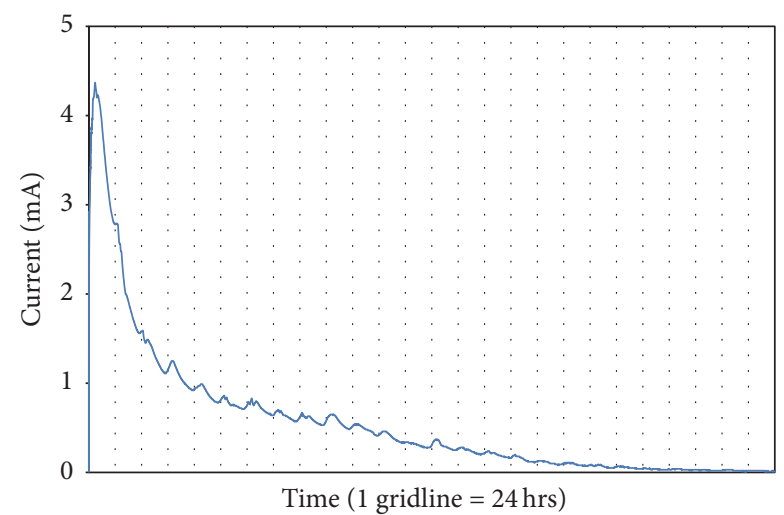

FIGURE 15: Final battery current discharge curve across $10 \Omega$ resistor (note: this is not a logarithmic scale).

and adding high proportions of carbon black, plasticiser, salt granules, and silica fume. Changes to the electrolyte constituents or the electrode proximity and ratio showed no significant influence on the time taken for the current output to plateau. However, changing the electrode material had a significant influence, particularly in the $\mathrm{Mg}$ : $\mathrm{Cu}$ cell. A final battery was designed as per Table 5 which has a high water/cement ratio of 0.6. Although carbon black is inert, it is similar in density to silica fume and its inclusion has been shown to increase the strength of cement mixes [27]; therefore, if both carbon black and silica fume are considered as pozzolanic materials, the presented mix water/cement + pozzolan ratio is 0.54 .

As shown in Figure 15 the lifespan of the battery was considerably higher than the previous designs lasting 21 days. The quasi steady $10 \Omega$ resistor-loaded current taken from three days after the initial peak $(4.37 \mathrm{~mA})$ over a 12 -day period was $0.59 \mathrm{~mA}$.

The discharge curve has a similar shape to the previous battery design that used magnesium as the anode ( $\mathrm{El} 1 \mathrm{in}$ Figure 14) with a curved peak and slow decline. The peak current achieved (4.37 mA) was also similar to El 1 (4.13 mA). However, there was a considerable increase in lifespan when comparing these batteries, from $40 \mathrm{hrs}$ to $505 \mathrm{hrs}$. Furthermore, the average quasi steady discharge current of $0.59 \mathrm{~mA}$ lasted only $19 \mathrm{hrs}$ for El 1 (Figure 14) increasing to $288 \mathrm{hrs}$ for the final battery (Figure 15). As the anode and cathode materials and sizes were the same for both batteries, this enhancement in both current and longevity can be attributed to the design of the electrolyte which provided more carbon black, higher water content, and the introduction of silica fume and Epsom and Alum salts. This battery type can provide over $1 \mathrm{~mA}$ through the $10 \Omega$ resistor for 4 days and a quasi steady current of $0.59 \mathrm{~mA}$ with a lifespan of over 21 days.
Further development of cement batteries found that sealing the electrolyte can increase the current output by $50 \%$ and that the capacity can be successfully increased by connecting cells in parallel [38].

\section{Conclusion}

This paper presented the findings from a study into the design of cement-based battery blocks. The study investigated the influence of water content, anode to cathode surface area, various additives, electrode type, electrode spacing, and the addition of carbon black. Previous work in this area developed a layered cement-based battery which produced small electrical outputs with a very short discharge life. The results here present much improved battery designs with higher electrical outputs and lifespan. In the cement electrolyte the use of higher $\mathrm{w} / \mathrm{c}$ ratios, carbon black addition with plasticiser, Alum and Epsom salts, and silica fume all increased the voltage, current, and lifespan. A magnesium anode and a copper cathode proved to be the most effective electrode combination of those studied producing an adequate cathodic protection current for $1 \mathrm{~m}^{2}$ of submerged concrete of for 4 days. Testing is ongoing to increase the lifespan and current output through constituent design and sealing methods. Initial tests into recharging the batteries using photovoltaics have been promising.

\section{Conflicts of Interest}

The authors declare that they have no conflicts of interest.

\section{Acknowledgments}

This research was funded by Science Foundation Ireland's Technology Innovation Development Award (SFI TIDA).

\section{References}

[1] T. R. Kuphaldt, Lessons in electric circuits, 1, 2006.

[2] Q. Meng and D. D. L. Chung, "Battery in the form of a cementmatrix composite," Cement and Concrete Composites, vol. 32, no. 10, pp. 829-839, 2010.

[3] R. Ashrafi, D. K. Sahu, P. Kesharwani, M. Ganjir, and R. C. Agrawal, "Ag+-ion conducting Nano-Composite Polymer Electrolytes (NCPEs): synthesis, characterization and all-solidbattery studies," Journal of Non-Crystalline Solids, vol. 391, pp. 91-95, 2014.

[4] B. Sun, J. Mindemark, K. Edström, and D. Brandell, "Polycarbonate-based solid polymer electrolytes for Li-ion batteries," Solid State Ionics, vol. 262, pp. 738-742, 2014.

[5] N. U. Taib and N. H. Idris, "Plastic crystal-solid biopolymer electrolytes for rechargeable lithium batteries," Journal of Membrane Science, vol. 468, pp. 149-154, 2014. 
[6] B. R. Shin, Y. J. Nam, D. Y. Oh, D. H. Kim, J. W. Kim, and Y. S. Jung, "Comparative study of $\mathrm{TiS}_{2} / \mathrm{Li}$-ln all-solid-state lithium batteries using glass-ceramic $\mathrm{Li}_{3} \mathrm{PS}_{4}$ and $\mathrm{Li}_{10} \mathrm{GeP}_{2} \mathrm{~S}_{12}$ solid electrolytes," Electrochimica Acta, vol. 146, pp. 395-402, 2014.

[7] M. Tatsumisago, R. Takano, K. Tadanaga, and A. Hayashi, "Preparation of $\mathrm{Li}_{3} \mathrm{BO}_{3}-\mathrm{Li}_{2} \mathrm{SO}_{4}$ glass-ceramic electrolytes for all-oxide lithium batteries," Journal of Power Sources, vol. 270, pp. 603-607, 2014.

[8] M. Tatsumisago and A. Hayashi, "Superionic glasses and glassceramics in the $\mathrm{Li}_{2} \mathrm{~S}-\mathrm{P}_{2} \mathrm{~S}_{5}$ system for all-solid-state lithium secondary batteries," Solid State Ionics, vol. 225, pp. 342-345, 2012.

[9] P. Stutzmann, Hydration and microstructure of portland cement paste, 2014 http://iti.northwestern.edu/cement/monograph/Monograph5_5_1.html.

[10] S. A. Ouellette and M. D. Todd, "Cement seawater battery energy harvester for marine infrastructure monitoring," IEEE Sensors Journal, vol. 14, no. 3, pp. 865-872, 2014.

[11] G. S. Rampradheep, M. Sivaraja, and K. Nivedha, "Electricity generation from cement matrix incorporated with self-curing agent," in Proceedings of the 1st International Conference on Advances in Engineering, Science and Management, ICAESM2012, pp. 377-382, India, March 2012.

[12] G. Qiao, G. Sun, H. Li, and J. Ou, "Heterogeneous tiny energy: an appealing opportunity to power wireless sensor motes in a corrosive environment," Applied Energy, vol. 131, pp. 87-96, 2014.

[13] N. Holmes, A. Byrne, and B. Norton, "First steps in developing cement-based batteries to power cathodic protection of embedded steel in concrete," Sustainable Des and Res (SDAR), 2015.

[14] G. T. Burstein and E. I. P. Speckert, "Developing a battery using set concrete as electrolyte," in Proceedings of the Metal/Air and Metal/Water Batteries - 210th ECS Meeting, pp. 13-20, Mexico, November 2006.

[15] M. Orazem, Underground Pipeline Corrosion, Elsevier Science, 2014.

[16] British Standards Institution. BS EN 197-1: Cement: composition, specifications and conformity criteria for common cements. London, 2000.

[17] R. B. Polder, "Cathodic protection of reinforced concrete structures in the Netherlands - experience and developments: Cathodic protection of concrete - 10 years experience," Heron, vol. 43, no. 1, pp. 3-14, 1998.

[18] R. Polder, J. Leggedoor, G. Schuten, S. Sajna, and A. Kranjc, Guideline for smart cathodic protection of steel in concrete, Assessment and Rehabilitation of Central European Highway Structures 2009.

[19] NORSOK Standardisation Work Group, “Common Requirements for Cathodic Protection", 1994.

[20] P. M. Chess and J. P. Broomfield, Cathodic Protection of Steel in Concrete, Taylor and Francis, 2003.

[21] A. M. Neville, Properties of concrete, Prentice Hall, 2011.

[22] W. J. McCarter, T. M. Chrisp, G. Starrs et al., "Developments in performance monitoring of concrete exposed to extreme environments," Journal of Infrastructure Systems, vol. 18, no. 3, pp. 167-175, 2012.

[23] P. Keil, D. Lützenkirchen-Hecht, and R. Frahm, "Investigation of room temperature oxidation of $\mathrm{Cu}$ in air by Yoneda-XAFS," in Proceedings of the X-Ray Absorption Fine Structure - XAFS13: 13th International Conference, pp. 490-492, USA, July 2006.
[24] Presearch Department. Carbon black magic turning electrically conductive plastics into products. P. Group, 2013.

[25] Q. Meng, Y. Kenayeti, and D. D. L. Chung, "Battery in the form of a soil-matrix composite," Journal of Energy Engineering, vol. 141, no. 3, Article ID 04014013, 2015.

[26] Z. Liu, Y. Zhang, and Q. Jiang, "Continuous tracking of the relationship between resistivity and pore structure of cement pastes," Construction and Building Materials, vol. 53, pp. 26-31, 2014.

[27] J. C. Maso, Interfaces in Cementitious Composites, Taylor and Francis, 2004.

[28] S. A. A. El-Enein, M. F. Kotkata, G. B. Hanna, M. Saad, and M. M. A. El Razek, "Electrical conductivity of concrete containing silica fume," Cement and Concrete Research, vol. 25, no. 8, pp. 1615-1620, 1995.

[29] D. D. L. Chung, "Electrical conduction behavior of cementmatrix composites," Journal of Materials Engineering and Performance, vol. 11, no. 2, pp. 194-204, 2002.

[30] S. Wen and D. D. L. Chung, "Seebeck effect in carbon fiberreinforced cement," Cement and Concrete Research, vol. 29, no. 12, pp. 1989-1993, 1999.

[31] C. Shi, "Strength, pore structure and permeability of alkaliactivated slag mortars," Cement and Concrete Research, vol. 26, no. 12, pp. 1789-1799, 1996.

[32] W. E. Martinsen, "Selected properties of sodium silicate glasses and their structural significance. Digital Repository at Iowa State University, 1969".

[33] D. Pantea, H. Darmstadt, S. Kaliaguine, and C. Roy, "Electrical conductivity of conductive carbon blacks: influence of surface chemistry and topology," Applied Surface Science, vol. 217, no. 1-4, pp. 181-193, 2003.

[34] R. Alcántara, J. M. Jiménez-Mateos, P. Lavela, and J. L. Tirado, "Carbon black: A promising electrode material for sodium-ion batteries," Electrochemistry Communications, vol. 3, no. 11, pp. 639-642, 2001.

[35] J. A. Shetzline and S. E. Creager, "Quantifying electronic and ionic conductivity contributions in carbon/polyelectrolyte composite thin films," Journal of the Electrochemical Society, vol. 161, no. 14, pp. H917-H923, 2014.

[36] Y. S. Ye, H. Wang, S. G. Bi et al., "Enhanced ion transport in polymer-ionic liquid electrolytes containing ionic liquid-functionalized nanostructured carbon materials," Carbon, vol. 86, article no. 9640, pp. 86-97, 2015.

[37] CM. Forman and EA. Verchot, "Practical galvanic series," US Army Missile Command, pp. 67-11, 1997.

[38] A. Byrne, N. Holmes, and B. Norton, "Cement based batteries and their potential for use in low power operations," in Proceedings of the 2nd International Conference on Innovative Materials, Structures and Technologies, IMST 2015, lva, October 2015. 

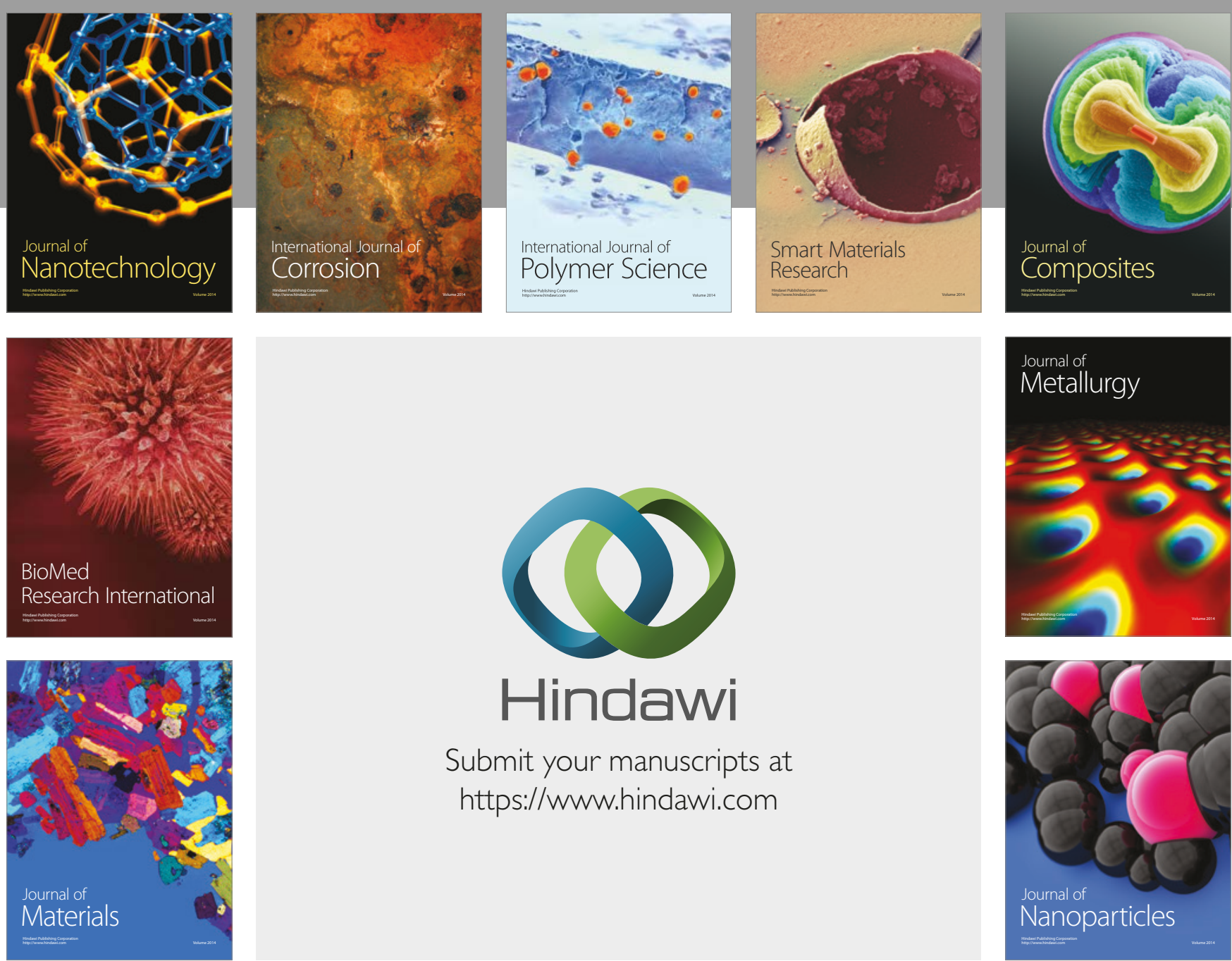

\section{Hindawi}

Submit your manuscripts at

https://www.hindawi.com
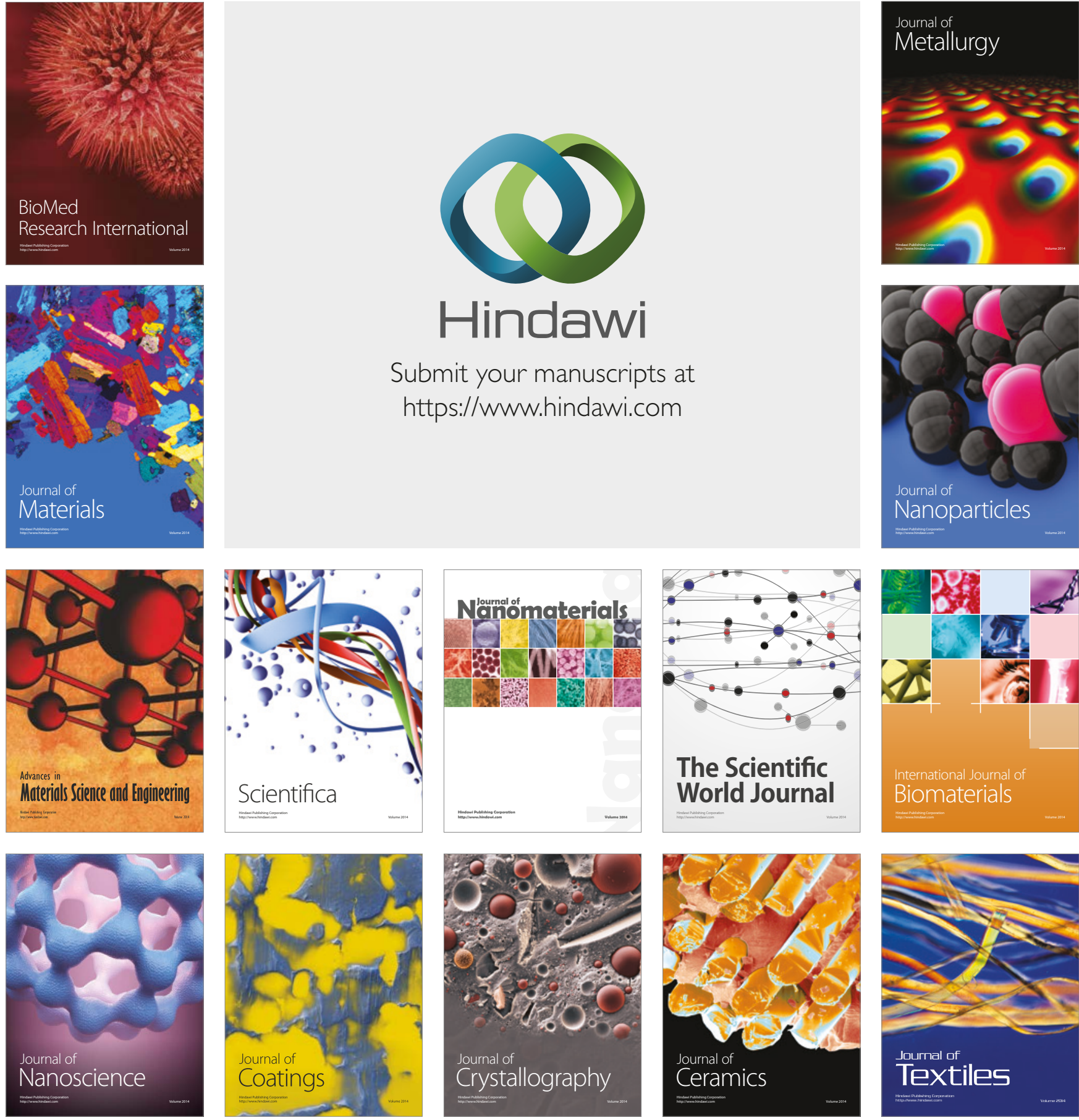

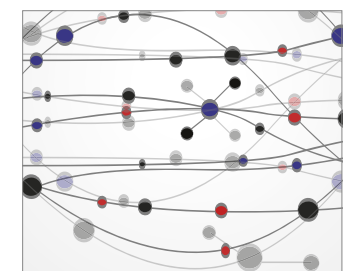

The Scientific World Journal
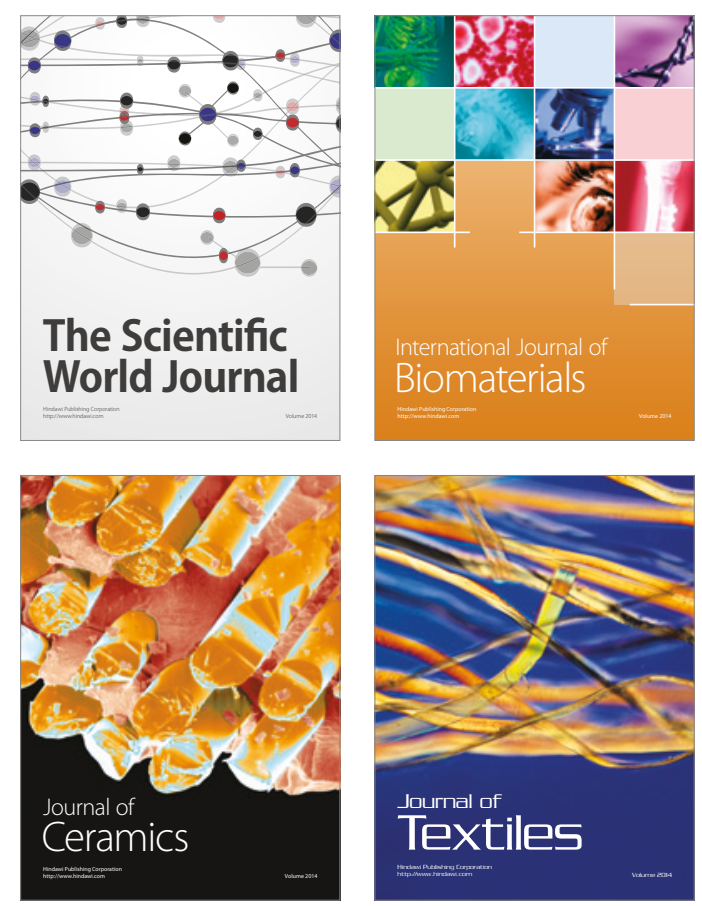